\title{
The Politics of Economic Crisis in East Asia: Some Longer Term Implications
}

Richard Higgott

CSG R Working Paper No. 02/ 98

March 1998
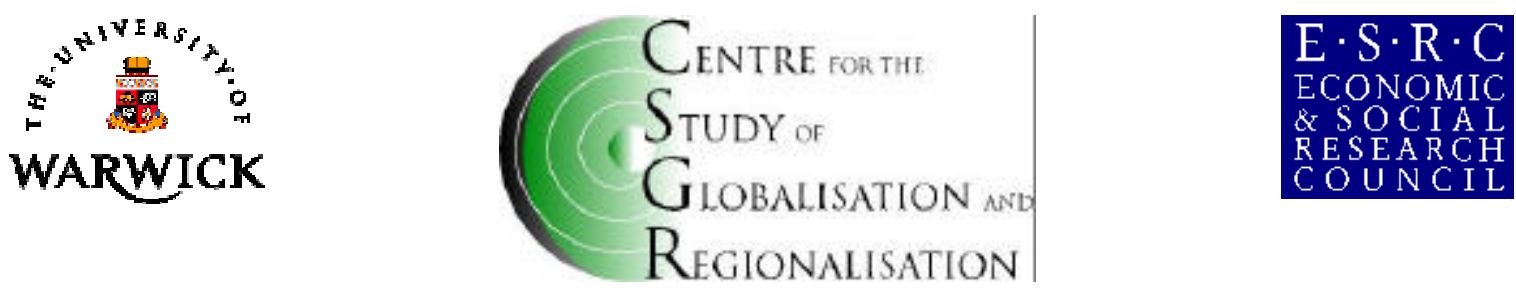

Centre for the Study of G lobalisation and Regionalisation (CSG R), University of Warwick, Coventry CV4 7AL, United-Kingdom. URL: http://www.warwick.ac.uk/fac/soc/CSGR 


\title{
The Politics of Economic Crisis in East Asia: Some Longer Tem Implications Richard Higgott University of Warwick and CSGR \\ CSG R Working Paper No. 02/ 98 \\ March 1998
}

\begin{abstract}
:
The currency and market turmoils in East Asia since summer of 1997 are every bit as much political crises as they are economic ones. Indeed, the political manifestations of these events may linger long after the necessary economic reforms have been introduced to return at least a semblance of economic normalcy to the region. This paper assess some of the longer term political implications. It does so through 'Asian tinted lenses' rather than Anglo American ones and offers an alternative reading of the East Asian economic crisis to that which exists in the mainstream of western policy analysis. While accepting that particularist explanations apply on a country by country basis, the paper outlines: (i) those aspects of the crisis that appear common to those countries affected to-date: (ii) the importance of the silent but fundamental role of Japan as a factor in the crisis and (iii) notwithstanding the real/ material explanations of the crisis, it argues that the crisis is in large part an ideological one reflecting a western conceptual inability to deal with the Asian model of development's reluctance to converge to with an Anglo-American form of capitalism

While the policy remedies proffered by the IMF are accepted in Asia in the short run, they may well not be appreciated in the long run and a major implication of this interaction may well be an enhancement of the prospect of the continued development of an 'East Asian' as opposed to 'Asia Pacific' understanding of region. Some evidence of regional social learning from the crisis that may well consolidate the trend towards enhanced economic policy coordination that already exists. This could exaccerbate tensions between global and regional interests and severely test the 'APEC consensus' on a commitment to neo-liberalism in the early stages of the twenty-first century.
\end{abstract}

Address for correspondence:

Professor Richard Higgott

Centre for the Study of Globalisation and Regionalisation,

University of Warwick,

Coventry CV4 7AL, United-Kingdom 
The Politics of Economic Crisis in East Asia:

Some Longer Term Implications

Professor Richard Higgott

University of Warwick

Business Challenges and Opportunities in the Asia Pacific Region

The Royal Institute of International Affairs

\author{
Chatham House \\ London 30 and 31 March 1998
}

(Prepared March 29, 1998. This is an uncorrected

first draft. Not for Citation in this form) 


\section{Introduction}

The currency and market turmoils in East Asia over the last nine months are every bit as much political crises as they are economic ones. Indeed, the political manifestations of these events may linger long after the necessary economic reforms have been introduced to return at least a semblance of economic normalcy to the region. In this paper I attempt to identify and assess some of the longer term political implications. I try to do so through what I think are Asian tinted lenses rather than Anglo American ones. As such, the paper offers an alternative reading of the East Asian economic crisis to that which exists in the mainstream of western policy analysis. It may also appear partial. But perceptions matter in politics and the perceptions I wish to present are, I would suggest, close to the hearts of many influential members of the East Asian public and private sector policy making elites. As such they are likely to influence the future of national economic policies in the region.

In section one, while accepting that particularist explanations have to apply on a country by country basis, the paper outlines those aspects of the crisis that appear common to all the countries--notably, Thailand, South Korea, Indonesia and to a lesser extent Malaysia and the Philippines--affected to-date. It also highlights the importance of the silent but fundamental role of Japan as a factor in the crisis. In addition, and notwithstanding the real/ material explanations of the crisis, it argues--in a highly contentious fashion I concede--that the crisis is in large part an ideological one that reflects a western conceptual inability to deal with the resistance of the Asian model of economic development to converge to, and conform with, an Anglo-American form of capitalism

In section two, the paper looks at the responses in Asia to the policy remedies proffered by the IMF and suggests that while the medicine will be swallowed in the short run, it will not be appreciated in the long run and a major implication of this interaction may well be an enhancement of the prospect of the continued development of an 'East Asian' as opposed to 'Asia Pacific' understanding of region. This assertion may run counter to contemporary conventional wisdom that in times of crisis the national urge to act independently comes to the fore. But the desire for national decision making autonomy in the face of economic crisis and the enhancement of a greater collective regional understanding in the wake of the crisis are not incompatible. Moreover, there is already some evidence of regional social learning from the crisis that may well consolidate the trend towards the enhanced economic policy coordination that gathered pace since the 
1980s. It is instructive that the Chinese character for crisis has two components 'danger plus opportunity' (Far Eastern Economic Review, January 8 1998, 15)

By way of conclusion, the paper argues that there are broader implications for thinking about the management of the global economic order in the twenty-first century--especially with regard to the re-regulation of international capital mobility, if indeed such reregulation might prove to be possible--that will emerge from the financial instability in East Asia in the closing stages of the twentieth century. This will demonstrate the tension between global and regional interests and severely test what I call the 'APEC consensus'-an unstated commitment to neo-liberalism--in the early stages of the twenty-first century.

\section{(1) 'Common Sense' and 'Not So Common Sense' Explanations of the Crises}

The broad outlines of a general explanation of the currency free fall in several East Asian states are now well known. _Speculative attacks on the worst affected currencies-initially the Thai Baht, but also the Korean Won, the Indonesian Ruppiah, the Thai Ringitt and the Phillipno peso--were spawned by the deflationary shock coming from China following the abandonment of the government controlled exchange rate regime in the summer of 1994 and which led to a 50 percent decline in the value of the Yuan. Compounded by the introduction of a 17 percent VAT rebate for exports, Chinese exports--at the high volume, low valued added end of the export chain--soared throughout 1996. This was largely at the expense of similar ASEAN exports on world markets. Unfortunately, ASEAN was also undermined at the sametime at the other end of the export chain--high value added exports in electronics and automobiles--following the politically manipulated decline in the value of the Japanese Yen since 1995.

It is thus no coincidence that Thailand was the hardest hit in the first instance. Throughout the middle years of the 1990s, Thailand had grown to be the largest producer of cars in the region. With no fewer than nine major auto producers from Europe, the USA and other parts of Asia, it had become the Asian export base for the global auto industry. (The big Japanese four held 80 percent of the market) Declining demand, not only in Thailand but in the region as a whole saw a $20 \%$ growth in 1993-5 turn into a 5\% decline in 1997. This was an important trigger to the financial fall out.

The over-valuation of the Thai Baht, and several other currencies, when compounded by 
the pegged nature of these currencies to the US\$ and the short-term nature of much of the debt that had arisen from speculative portfolio investment and which exaccerbated the massive, regional financial fallout. That this was a massive over reaction should come as not surprise. It is well understood in political economy how rational behaviour on the part of individual investors (or more precisely disinvestors) can lead to a collectively irrational response as 'disaster myopia'--the collective belief that everything is going wrong--takes hold.

The striking feature of the financial fallout in East Asia, and that distinguishes it from events in Latin America in earlier periods, is that it occurred in a disinflationary environment tied to the increasingly integrated nature of East Asia as an interdependent region of production (Hatch and Yamamura, 1996, Barnard, 1996) and the interdependent nature of the international economy as a global market. Rapid regional economic growth in the 1970s and 1980s had hidden the sloppy, inefficient and at times corrupt banking practices of the region that had prevailed during this period. What was not hidden was often been tolerated in the context the accommodatory alliance politics of the Cold War.

This in shorthand is the 'common sense' explanation of the currency crises in East Asia This explanation--especially the 'discovery' that all was not what it should be in the banking system--as a reading of the International Herald Tribune, the Financial Times and The Economist during the period August 1997-January 1998 tells us, have made it difficult for many western analysts to disguise a certain schadenfreude at the situations in which these states now find themselves. Even the most saintly of us would find it difficult to overlook the discomfort that comes in the wake of the escalating hubris-encapsulated in the 'Asian Way' and 'Miracle' clichŽs and epitomised in the words of leaders such as Dr Mahathir--that accompanied East Asia growth throughout the 1990s. Such readings, however, are superficial. Keen to capture the urgency of the economic crises and the essentially simple neo-classical economic reforms that are needed to resolve them, they downgrade an appreciation of the magnitude of Asian economic growth over the last two decades. For many commentators, the age of hyper rapid export driven growth is over. That this is a volte face of monumental proportions which should cause many policy analysts to tender their resignation is too delightful not to mention.

The 'common sense' explanations' also downgrade the manner in which the crises are not simply the result of a failure of 'rational' economic management as much as they are part of the wider processes of structural change that have gone on in the region and in which 
those states that are not part of the immediate crisis--especially Japan--are integrally interwoven. Indeed, Japan is central to the crises in a range of major ways. Notably, the Japanese model of economic development has acted as a template for the manner in which the other Asian miracle economies have developed. The 'developmental state' is very much a product of a reading of Japanese post world war two development. As I shall try to demonstrate, at the core of the recent economic crisis in East Asia is an incompatibility between the developmental statist and the anglo-american model of capitalist economic development.

This is not to suggest that Korea, Thailand etc. are facsimiles of the Japanese economy, rather than that Japan has been a source of inspiration--especially in the replication of the Japanese incentive structure--in the pursuit of policy (both implicitly and explicitly) over the last several decades. Moreover, as the principal investor in the East Asian region over the last several decades, Japan has had more than an informal role in shaping the productive structures of the other regional economies. It has had a direct role via the provision or withholding capital investment in the regional economies. Yet while Japanese capital helped developed the productive structures of the region throughout the 1980s, more recent cheaper credit from Japan fuelled the speculative investment capabilities of international financial houses that were so influential in contributing to the financial instability in East Asia in the mid 1990s.

While for all states of the region, North America was the major destination for exports, throughout the late 1980s and early 1990s, Japan was becoming an increasingly important market for East Asian exports. The 1995 devaluation of the Yen against the dollar has severely curtailed this market for East Asian exporters. As Karel van Wolferen in an excellent discussion of these issues notes (1998: 1) Japanese capital helped create over-capacity in the region without fulfilling the role of a market of last resort to absorb it.

The 'common sense' explanations also ignore the manner in which the policy reforms emanating from the international financial institutions are highly political in nature. For example, the popular, western view of the behaviour of the US and the IMF in the wake of the economic crisis in East Asia is that the IMF has effectively bailed out these Newly Industrialising Economies--especially South Korea, Thailand and Indonesia--that got themselves into trouble largely by acts of their own making. 'The United States played Santa Claus not Scrooge' as one analyst put it. (Howell, 1998: 1) 
That the acts that led to the immediate crisis may, in large part, have been self-inflicted by the policy elites of the region is not contested in this paper. That the response of the major economic powers and the international financial institutions has saved the day--and will be duly recognised and appreciated for doing so--is contested. In so doing, I wish to argue that the crisis (seeing crisis as both danger and opportunity) may lead to an increasing desire on the part of regional policy makers to enhance their collective as well as national policy making capabilities.

\section{(2) International Policy Reform and East Asian Political Reaction}

Let us consider briefly the prescriptions that have been proffered by the IMF. They were tried and tested initially in Latin America and Africa where the principal economic ills were large budget deficits, high inflation and massively indebted public sectors. In Asia, where both inflation and budgets deficits have been relatively low the problems have emanated largely from the private as opposed to public sector. (Far Eastern economic Review, December 25, 1997: 5) Indeed, a case can be made that the reform proposals advocated by the IMF--in essence, domestic austerity accompanied by financial restructuring--offer the wrong remedies.

As Robert Wade and Frank Veneroso (1998: 1-4) argue, it was excessive deregulation of the financial markets in the first instance that allowed Asian firms to engage in massive overseas borrowing. In the absence of government control on domestic companies, banking supervision, or even any policy coordination on borrowings and investment-those governmental conditions that had given stability to Asian development in the first instance--it gave rise to the real problem, 'illiquidity rather than insolvency'. Corporations began borrowing overseas more cheaply than at home Devaluations and enhanced productivity growth in China between 1991 and 1994, and the pegged nature of many East Asian currencies to a rising US dollar led to the sharp decline in the value of many of these currencies. Massive increases in debt and the rush of foreign investors to call in loans--many of which were short term in nature--led to the escalating crisis.

This process has undermined the 'High Debt Model of Asian Development', central to which has been a '...strong financial rationale for cooperative long term reciprocal relations between firms banks and governments.' Often referred to in the western press as 
'crony capitalism', ${ }^{1}$ this catchy, but misleading, aphorism belies the degree to which this relationship intermediates the functional connections between the high domestic savings (characteristic of Asian NIES and often as high as a third of GDP compared to the western average of about 15 percent) and the high corporate debt/equity ratios (equally characteristic of the Asian NIES.) (Wade and Veneroso, 1888: 2-4)

High household savings, plus high corporate debt/equity ratios, plus bank-firmstate collaboration, plus national industrial strategy, plus investment incentives conditional on international competitiveness equals the 'developmental state'. For all the white elephants and corruption (inevitable when a third of national income is intermediated), the system that allows firms to borrow multiples of their equity has yielded a quantum leap up the world hierarchy in technology and scale, and rates of improvement in living conditions that surpass virtually all other countries. (Wade and Veneroso, 1998: 3)

The analysis of Wade and Veneroso is not offered here as a defence of the grosser infelicities of Asian business culture, nor of the seriousness of high debt to equity ratio in times of currency devaluation (when it is much more serious than for countries with low debt to equity ratios.) Rather, it is offered as a starting point for thinking about likely regional political responses to the 1997/8 economic crisis in East Asia and especially Asian longer term responses to the neo-liberal (IMF) approach to reform.

Viewed through Wade and Veneroso's lenses, IMF remedies--domestic austerity and financial restructuring based on a western understanding of liberalisation ${ }^{2}$-seem more likely to erode rather than boost investor confidence. IMF policies that are aimed at cutting demand and liquidity have the effect of causing bankruptcy and slashing the value not only of companies that are inefficient and unprofitable but also those which are not so

1 'Cronyism' was originally used to describe the politics of Ferdinand Marcos' regime in the Philippines. It has now come to be used as a generic term in the region. This, to my mind, illustrates a considerable intellectual deficit on the part of contemporary analyss of the political economy of East Asia.

2 Measures propsosed for Korea, Indonesia and Thailand aimed at financial deregulation and liberalisation and domestic demand containment include abandoning crippled financial institutions, making provision for international purchase of domestic financial institutions; internationalising domestic accounting and auditing activities--in both theory and practice; the elimination of government directed lending and non intervention in commercial banking; removal of government assistance, including tax privileges, to domestic corporations as well as more rapid liberalisation of the trade regime and the labour market. 
afflicted. In so doing IMF strategies can undermine the advantages inherent in the high debt model without putting in place a viable 'western style' alternative--which cannot take hold without the removal of the debt mountain in the first instance.

If these debts cannot be repaid or whittled away by inflation then it would appear that it is only by bankruptcy or debt for equity swaps that it can be controlled. For either to happen, large sections of the economies of the Asian NIES would disappear or end up in foreign control. Both are theoretically possible and the latter most likely in any circumstance given that the devaluations offer knock-down bargains for cashed-up foreign buyers. Japanese and US investors can, and will, move easily from minority to majority shareholders in Southeast Asia by the tactic of writing down Asian partner debt.

The prospects of a socio-political backlash against this course of action is all too evident. At the popular level, the currency devaluation and demand-restricting austerity measures have seen riots in Thailand, Indonesia and South Korea. At the elite level, increased foreign ownership of the corporate sectors of the East Asian NIES virtually begs forth a heightened nationalist response, although the exact form it will take is not yet easy to identify. If it does not lead to reneging on IMF policy over the next few years it is certain that the implementation of IMF agreements will be less than enthusiastically pursued.

The most dramatic response--a debt moratorium on the part of major regional debtors such as South Korea--has proved improbable for several reasons. Firstly, the structural constraints of globalisation are too strong. Second, there are other strong reasons (especially of a security nature) for not antagonising the US by such a course of action. Third, the commitment to neo-liberalism of the policy elite in Korea is not so weak as to make a moratorium a thinkable policy option. But is some form of debtors cartel with Thailand and Indonesia possible? Evidence can be found in a daily reading of the Thai, Indonesian and South Korean press of the local political resentment at what are seen as the draconian nature of the IMF packages and the need to loosen them. Such responses may get stronger over time. (Far Eastern Economic Review, January 22, 1998: 21)

This analysis of the crisis also begs consideration of a number of wider questions. If the USA and the IMF have their way, then a western model of liberalisation, replacing the Asian 'high debt model' may come into place overtime. Alternatively, it could also see a hardening nationalist resistance to neo-liberalism. For what has been challenged in the crisis of the East Asian NIES in the late twentieth century is the very model on which they 
have built their success. It should be seen not only as an economic crisis, but as an 'ideas battle' or an ideological battle. Having 'won' the Cold War against Soviet style collectivism, no sooner is one bout of triumphalism over than liberalism is now gleefully protesting its superiority over the 'developmental statist approach towards capitalist economic development. This may not play well in the long run in East Asia and can expect to fuel Asian resentment at the policy responses it has been forced to adopt.

That the Asian model would have to have changed after the end of the Cold War anyway does not undermine the prospects for growing resentment in the region. During the Cold War US willingness to supply official capital and to open its markets for an initial one way flow of exports was predicated heavily on the security consideration of containing communism. In a more benign security environment, American concerns that it was becoming a 'normal country', or that many of its former junior partners in the Pacific alliance were continuing to free ride when no longer necessary, saw an increasing clamour in the US policy community for change in the region.

Regional economic trade liberalisation and financial de-regulation were meant to be the American pay-off for a continued security presence in the region. While both were assumed to be mutually beneficial, it has become increasingly clear to Asian policy makers that the latter has had much greater significance than the former. Those sociopolitical practices of the so-called Asian model that were acceptable for security reasons during the Cold War--exclusionary politics, nepotism and the blurred lines of authority between political and economic power--now clash more violently with the interests if private capital in search of greater market share and profits in an era of deregulation.

Yet as important as such factors are in impeding domestic structural reform, to lay the blame for the economic problems in East Asia solely or even primarily, on the seamy side of so-called Asian values would be to miss the point. The essence of Asian values--if indeed there be any--are thrift, hard work and respect for ones parents. These are unlikely to be the source of economic failure. On the other hand, corruption and cronyism-deemed to be crucial factors--are not peculiarly Asian in their origins. Rather as the Far Eastern Economic Review (February 12 1998: 47) notes, it was a '...potent mix (emphasis added) of globalisation, poor governance and greed that brought about the crisis. ${ }^{3}$

3 It is not a defence of Asian values to suggest instances of such can be found in non-Asian societies, as for example in the Savings and Loans scandal in the US, in arms dealings between the UK and several Arab 
Not the least aspect of this process has been the herd like behaviour of the financial markets. If the optimism that generated the high inflows of capital to the region was excessive than so too has been the market panic that saw the process reversed in a few short months. Those international investors who thought the East Asian NIEs could do no wrong until early 1997 appeared after that date to think they could do nothing right. Between 1994 and 1996 net private inflows into Indonesia, Korea, Malaysia, Thailand and the Philippines grew from US\$48b to US\$93b. The figure for 1997 was minus US\$12b (The Financial Times, February 16, 1998: 21) thus causing panic and the ensuing currency and business collapses well beyond what the underlying economic situation has warranted.

However, most East Asian political elites now accept that their current problems are unlike those of the mid 1970s and mid 1980s--both of which were largely externally driven--and from which Asia economies bounced back quickly. Contrary to the initial arguments of the kind advanced by Dr Mahathir, the crisis was recognised around the region to be largely internally driven and much deeper than anything hitherto experienced. Regional leaders have recognised that the currency and stock market collapses (excessive as they might be) arose from a combination of property booms and other bad investments on the one hand and mismanagement, corruption and inefficiency in both public and private decision making sectors--especially the cosy relationship between governments and business--on the other. Crony capitalism may be an insufficient explanation of the magnitude of the crisis, but the Southeast Asian middle classes hold their political and economic elites accountable for the mess.

It is recognised that adjustment will be painful and entail what is known in the region as 'creative destruction' in which some banks and business houses must fail. Thus the real question, in both the short and longer term, is the degree to which regional economic and political leaders will be willing, and/or able, to grasp the nettle of economic adjustment in an era of potential political instability that will accompany the generational transition

States and in Germany, where bribes to foreign officials in the hunt for contracts are still tax deductible. But the essence of the Saving and Loans scandal in the US--a private sector insulated from the costs of its decisions because banks lent money while government assumed the risk--is very similar to the problems that beset Asia. The difference is not one of style but one of substance. While no exact estimation is possible, bad loans in East Asia can count for anywhere between 15-25 percent of total loans. This contrasts with a figure of 1percent in the USA. The Savings and Loan Crisis took about 2 percent of US GDP to sort out. Estimates for Southeast Asia in late 1997 were about 13 percent of regional GDP. This will almost certainly rise throughout 1998. 
processes in train in many countries. This remains an open and multi-dimensional question, but there is a range of circumstantial evidence that has emerged throughout the crisis that points towards a 'regionalisation of thinking' on these issues.

For example, the main donors for the initial financial adjustment package to stem the haemorrhage of the Thai economy in late 1997 were Japan (\$US4b) Korea and Taiwan (\$US2b) Australia and the PRC (\$US1b) All were from the region. Their motives may have been mixed but this is less important than their demonstrable desire to be involved in the process. All states in their own ways were attempting to consolidate their regional positions in both an economic (de facto) and political (de jure) fashion. Conversely, the US unwillingness to support it generated considerable resentment.

Moreover, not only did the US refuse to support the package, it also opposed regional calls to set up a $\$ 100$ billion 'Asian only' bail-out. This was to be underwritten by Japan to provide emergency support in a regional way and avoid what many leaders saw as the humiliation of the IMF telling them how to readjust to the new circumstance. The initiative was always a long shot but it gained initial Japanese backing and even led to talk of a permanent regional fund. 4

More importantly, the proposal had interesting consequences. It galvanised the USA and the IMF (for purposes here the two are indistinguishable) into strongly reasserting their position that adjustment funds not under the direct or indirect control of the IMF might not be 'properly used'. Their desire to control adjustment funding has, for the time being, prevailed. But, in so doing, seeds of a polarisation of the Asian and Caucasian members of APEC may have been sown. Subsequent arguments about the role that the IMF should play in the rescues in the region, especially in Indonesia and South Korea, were only resolved in favour of the IMF taking the lead role after considerable argument.

Notwithstanding the humiliation of calling the IMF--especially in Korea, recently admitted to the OECD--the dominant role for the organisation was decided at a meeting in Manila and endorsed at the Vancouver APEC meeting in late 1997. APEC backed an IMF led response to Asia's problems. Any idea of a special (regional) assistance

\footnotetext{
${ }^{4}$ Recent American support for the Thai economy is seen as an attempt to offset the adverse effect on Thai US relationsh of the initial US unwillingness to offer support. The Financial Times, March--CHECK REF.
} 
programme was scotched by the US, as were Dr Mahathir's attempts to tighten currency regulation. In effect APEC endorsed a standard model of macro-economic policy reform--with all the accompanying implications of painful restructuring processes for most countries of the region. This may, however, be a turning point for the organisation. The exhortatory liberalisation rhetoric of the Vancouver APEC only superficially concealed a deeper schism within its ranks after the crisis--between the two edges of the Pacific. The recent economic turmoil has reinforced the notion that the Asia Pacific is an artificial construction of region, the long term salience of which may well have been affected by the economic downturn, or more specifically by the prospect of longer term regional resentment at the US and IMF led responses to the crisis.

IMF style solutions to reform may represent defensible economic theory, but they are also a manifestation of US power representing a threat to extant patterns of political and economic power in the region. Policy elites may take, digest and implement their liberal adjustment medicine in the wake of the crisis, but in looking to the future, the liberal agenda of APEC is likely to resonate less with regional decision makers. Asian leaders may develop a dialogue that may lead to a new form of cooperative regional surveillance. Indeed, the acceptance of IMF medicine has been accompanied not only by grumbling but also by growing regional support as other members of the region have contributed, albeit in a bilateral and limited manner, to the overall packages.

For example ASEAN finance ministers (meeting in Manila 1-2/12/1997) inspired and agreed a framework whereby member states would engage in the mutual surveillance of each others economies. Such an agreement, unthinkable prior to the crisis, demonstrates a desire to enhance regional policy making capabilities and process--especially if they are entering a period in which they are going to provide contributions to each others reform processes. This is a significant exercise in the recognition of the East Asianness of the region and the crisis has been a spur to it. While it was anchored within the existing international financial institutional context, the Manila framework is intended to 'Enhance Asian Regional Cooperation to Promote Financial stability'.

The Manila Framework is very much part of the wider exercise of soul searching that is now taking place both within ASEAN and between ASEAN and its other East Asian partners. Hadi Soesastro, one of the intellectual 'architects' of regional cooperation in East Asia over the last decade has suggested that ASEAN is facing an identity crisis and that it might be necessary to reconsider some aspects of the ASEAN way of 'non- 
interference' in the affairs of member states. As he recently noted, Malaysian Deputy Prime Minister Anwar Ibrahim's call for "constructive involvement" in ASEAN is but a euphemism for intervention. ${ }^{5}$

The formula adopted at Manila was portrayed in certain sections of the US media as a US defeat of Japanese attempts to establish a fund without IMF style conditionality. As Barry Wain has demonstrated this is an unfair reading of Japanese behaviour. Indeed, their offer came only in response to the widespread regional disappointment at the US failure to support the IMF package for Thailand. The notion of a regional fund only ever existed in the minds of Dr Mahathir and a few other Malaysians and Indonesians. (The Asian Wall Street Journal, December 12-13, 1887: 6.)

The Framework was supported by all at Manila--the ASEAN core, plus the East Asian economies of Japan, China, Hong Kong and Korea and the Caucasian members of APEC. Also present at the meeting were officials from the IMF and the WBG. The Manila Framework will operate on an ASEAN plus basis (East Asia without Australian, and New Zealand). For obvious reasons, the US will be present and the Asian Development Bank will provide a secretariat. The Framework will offer a process of mutual surveillance and 'peer pressure' of an Asian variety. In short it represents a contribution to the regional institutional economic architecture that does not currently fit with any existing model.

The role of the US and the IMF has been crucial in a range of other ways. The ambivalent--what we might call love-hate--relationship that has always existed between the states of East Asia and the USA and US led institutions, has been brought into sharp relief by the collapse of the East Asian currencies and the subsequent process of international financial institution intervention. As time progresses, the nature of the bailout seems to become increasingly problematic. The authority of the IMF would have been accepted more by the state policy elites of East Asia if the interventions had indeed rapidly restored market confidence and stability. But for many in the region--and not only Dr Mahathir--the crisis appears rather to have presented the IMF with the opportunity to force open East Asian economies in two major ways. First, conditionality attached to the bailout packages will allow international banks to make major inroads into the regions banking sectors. ${ }^{6}$ Second, 'liberalising' conditions beyond 'normal' macreconomic targets

\footnotetext{
5 Seosastro, speaking to a conference on Regionalism and Global Affairs in the Post Cold War Era: The European Union, APEC and the New International Political Economy, Brussels, March 26-27, 1998
} 
will pave the way US firms to achieve unprecedented market access.

But most resented of all in the region is a strongly and widely held view that there is a double standard present in the IMF insistence that regional governments not rescue local financial institutions while at the same time insisting that they guarantee the repayment of international loans, thus alleviating foreign lending houses from any 'moral hazard'. To the educated populations of the crisis hit countries of the region this is seen as local entrepreneurs paying for their mistakes while the mistakes of foreign investors are underwritten at local expense. Judging by demonstrations in Bangkok, Seoul and Jakarta, there can be little doubt that the populations of East Asia are keen to see their leaders held accountable for their mistakes. But there is also a strong belief that foreign banks are escaping the costs of their commercial mistakes thus undermining the legitimacy of the externally coerced policy recommendations from the IMF. In short, IMF policies are seen in the region as designed to save western investors, not to save Asian economic development. Going even further, one Malaysian analyst noted:

What the rich could not do through bilateral and multilateral pressures, they are now extracting by using the IMF loans as leverage.....No wonder the IMF's main role in Asia is increasingly seen as chief debt collector for international banks. (Khor, 1998: 29)

It is all well and good for western analysts to say that this is a partial reading of these processes. It may be, but perceptions count and this perception prevails in East Asia in the early 1998. For sure, some of the more enthusiastic investors in Asian stocks have paid heavy prices, but to many Asians the end result of the rescue packages appears just as Dr Mahathir, at his most bellicose, predicted. The real bailout, as far as many Asians are concerned has not been of their economies but of the foreign investment houses which lent the money and that are though to be as much responsible for the problem as the local business that borrowed from them.

A further objection is to be found in the widely held view that the IMF itself does not

6 It has happened already in Thailand where Citibank is taking a majority share in a major Thai bank. In South Korea, where IMF adjustment package support was contingent on a range of 'reforms' in the financial sector, including allowing for the prospect of majority foreign ownership of Korean bank and the estbalishment of subsidiaries and brokeage houses by December 1998, the way is open for a major foreign stake in the Korean financial sector--see Khor $(1998,29)$. 
practice what it preaches. It demands transparency and openness in the policy making processes of the Asian states but shrouds its own operations in secrecy. As Jeffrey Sach's The Observer, 1998, February 8, 1998: 5.) has noted, the theoretical underpinnings of its own policy advice are not even available for scrutiny by other policy professionals.

In this regard, the Asian crisis is a contest of ideology between Asian and Anglo American ways of organising capitalist production. Alan Greenspan, of the US Federal Reserve Bank has publicly argued that the crisis in East Asia's currency markets will have the effect of moving East Asian economic practice closer to that associated with the US model. In this regard, the crisis is an weapon in the normatively laudable process of convergence for many Western analysts. Only time will tell if he is correct or not. One does not have to accept the cruder versions of this analysis--which suggest that the IMF is merely an instrument of US policy doing Treasury Secretary Rubin's bidding in attempting to bring Asian economic policy making into line with the dominant approach of the US--to recognise an important test of intellectual will is in train.

This analysis does not ignore the role of the IMF as a valuable instrument to stem panic and to bring short term stability to economies in distress. Indeed, Asian leaders recognise the importance of the IMF in this role. The IMF did not cause the crisis and, as senior figures in the regional policy communities note, it is correct that the IMF should play hard ball to secure some aspects of policy reform in the region--especially in Indonesia. What is questioned by regional leaders--of all political stripe--is the role of the IMF as an instrument of ideological change. Many of the reform packages are thought to have gone beyond traditional structural reform strategies, designed not only to restore stability to the regional financial markets and reform banking sectors, but to actually contest the nature of the political process and the power base of the political elites of the region. This has certainly been the case in Indonesia where the President saw Indonesian technocrats making common cause with the IMF to challenge the power base of the Suharto family. ${ }^{7}$ Whether this is normatively a good thing is of little concern to the argument presented here. More important is to note that the this is the role that is perceived to have been taken on by the IMF and it is one that Asian leaders feel obliged to resist.

${ }^{7}$ Confidential discussion with the head of a major Indoensian think tank, March 271998 


\section{Conclusion: A Future Imperfect for International Economic Governance?}

This paper has offered an alternative reading of the East Asian economic crisis to that which exists in the mainstream of western policy analysis. But it is, I would suggest, close to the hearts of most members of the East Asian public and private sector policy making community than is acknowledge in either the popular or scholarly literature. If it is a correct reading of regional opinion it is one that is likely to influence the future of national economic policies in the region. If it is not, then it is still one that should act as a moderating influence on some of the more triumphalist analyses of the Asian political economy that have emanated from western scholars and policy analysts over the last nine months--a period in which Asian hubris has been swapped for Western hubris I think.

If the argument of the paper has substance it can be also expected to have longer term implications for the international relations of the Asia Pacific region. The economic meltdown is seen as the darker side of globalisation, and not just in the more vocal states such as Malaysia. Even while praising the planned reforms of Thailand's financial system (including only allowing 2 of the 56 financial houses that had been suspended from trading to re-open) the Bangkok Post (December 9, 1997: 3) argued that 'the juggernaut of globalisation' must not become a vehicle of a 'global monoculture.'

For many Asians the feeling that there was an exploitative element to the north-south relationship had never really been eradicated as a component in the Pacific economic dialogue in fora such as APEC over the last decade. The nature of the IMF reform packages, and especially the 'school marmish' manner in which they have been imposed has brought this north south-divide back into the open in the relationship between the Caucasian and East Asian members of APEC. Many Asian regional public and private sector policy makers share Wade and Veneroso's view that under the influence of the US Treasury and Wall Street's desire to secure open global financial markets, '...the IMF "bail out" is more like a "bail in" for foreign corporations.' Wade and Veneroso, 1998: $15)$.

Such feelings give rise to resentment and resistance not only within the domestic polities and societies of the region, but also at the level of the trans-regional policy making communities that had supposedly been making strides towards greater economic dialogue and harmonisation of economic policy making across the Asia Pacific within bodies such as APEC. The crisis demonstrated the limited utility of APEC. As a body capable of 
making decisions of regional utility it was paralysed by the crisis. The effect of this was that the US effectively went it alone and drove through the so-called Washington consensus style IMF reform packages. In so doing, the crisis has made the gap across the Pacific greater rather than smaller. A putative regional economic grouping--like the East Asia Economic Caucus (see Higgott and Stubbs, 1995)--may prove more conducive to the interests of regional policy elites in the long term than APEC. Unlike APEC, EAEC is unambiguously 'regional' and may be a more comfortable ideological venue for East Asia's political leaders.

The tension between the IMF and the Asian view of managing the regional economic order is in a delicate balance. Dr Mahathir may have lost touch with reality in his tirade against the tyranny of the markets, but in his view that the economic crisis confirms the dangers of too much economic liberalisation for East Asia he has hit a strong regional chord. To Asians it appears that no one is in charge of the financial markets. This lack of order does not sit well with East Asian leaders. Notwithstanding the recent intellectual battering of the 'Asian Way', its greater permissiveness toward state intervention may not have yet run its course. We may see some reform that makes Asian governmental structures leaner, more transparent and less receptive to rent-seeking behaviour but it is unlikely that all elements of the 'developmental statist' model will be torn up in the interests of a purer Anglo-American neo-liberalism. To assume such is to under estimate the degree to which the economic systems of East Asia are strongly societally anchored.

At the global level, regulatory complexity and the problems of the management of international financial markets, monetary relations and trade policy remain key questions for all governments at the close of the twentieth century. Some rules, norms and institutions for the management of some aspects of globalisation exist, but they are not sovereign. The framework that emerged under American hegemony in the post-world war two 'Bretton woods era' has unravelled. Reconstructing a stable institutional framework is not easy in a post-Keynesian, post-monetarist, post-welfare state and post-Cold War era of dramatic economic change and new found freedoms. At the regional level, the most established regimes (cf. the EU) exhibit fundamental concerns over their future direction while at the other end of the spectrum regimes such as APEC are still so rudimentary as to be considered at best instruments of dialogue as opposed to instruments of governance.

The desire to enhance supervision of private cross border flows, especially FDI in emerging markets can be expected to grow quite dramatically in the wake of the recent 
experiences in East Asia. Nothing is likely to shake the view held in many Asian capitals that the markets punishment of the weaknesses in the financial systems of the region--real as these weaknesses are--far exceeded the crime. If the economic crisis in East Asia is to provide a positive learning experience at the multilateral level, as opposed to a negative-resentment generating--learning experience at the regional level, it must trigger a discussion of the knee jerk assumption that the unfettered movement of capital (especially short term lending) is axiomatically a good thing. As even the Financial Times (January 16, 1998: 18) recently noted, '...the wisdom of over-hasty integration of emerging economies into global financial markets must be reconsidered.'

Globalisation requires the development of institutional capability for prudential regulation in these areas. If not, speculative portfolio capital will continue to wing its way around the world as pat of the under-regulated global competitive game. While most policy analysts recognise regulation--or more appropriately, re-regulation--is best pursued at the global level, regional level initiatives of the type outlined in the Manila framework can be expected to evolve. In a post-hegemonic era there is no 'lender of last resort'. Asian states must look to self help at the regional level as much as to the institutional resolution of these issues at the global level.

The events of 1997/8 have been some of the most traumatic experienced in Asia since the periods of decolonisation and Cold War confrontation in the 1950s and 1960s. They have cause a fundamental rethink on a range of issues. They have also side tracked policy elites from the regional dialogue activities that became increasingly popular throughout the first half of the 1990s. As the immediate crisis recedes and policy elites begin to think again more constructively about the regional cooperative agenda, the events of 1997/8 will need to be put into clearer analytical perspective. We can expect the development of multi-level regionalism in Asia to continue. At the very least, East Asia will be at the core of the new regionalism. The Asia Pacific, as constituted by the membership of the APEC, will form the outer shell. Broad economic philosophies principally liberal in nature will continue to underpin both the inner core and outer shell-especially a commitment to freer and open trade and the multilateral trading system. The economic crisis will continue reform of a market opening nature. But there will be a different regional spin towards these global issues in East Asia that will reflect more strongly Asian cultural and economic experiences and which will lead to enhanced Asian policy responses to the major global economic questions of our time. East Asian policy makers may be less willing in the early stages of the next century to subscribe to the 
tenets of neo-liberalism than they have been in the closing stages of the current one. 


\section{References (Does not conform uniformly to this paper at this stage)}

Amitav Acharya, (1997) 'Ideas, Identity and Institution Building: from ASEAN Way to Asia Pacific Way', The Pacific Review, 10 (3): 319-46.

Emmanuel Adler and Beth Crawford, (19910 (eds) Progress in Post War International Relations, New York: Columbia University Press.

Susan Berger and Ronald Dore (1996) (eds) National Diversity and Global Capitalism, Ithaca: Cornell University Press.

Jagdish Bhagwati and Arvind Panagariya, (1996) 'Regionalism versus Multilateralism: The Theory of Preferential Trade Arrangements: Historical Evolution and Current Trends', American Economic Review, 86 (2): PPs to follow

Hedley Bull (1977) The Anarchical Society, London: Macmillan.

Vincent Cable (1995) 'The Diminshed Nation State?' in What Future for the State? Daedalus, 124 (2): 23 53.

-and David Henderson, (1994) Trade Blocs? The Future of Regional Integration., London: Royal Institute of International Affairs.David Camroux and Christian Lechervy (1996) 'Encounter of a Third Kind: The Inaugural Asia Europe Meeting', The Pacific Review, 9 (3): $442-53$

M. G. Cowles, (1995) 'Setting the Agenda for the New Europe: The European Round Table and EC 1992', Journal of Common Market Studies, 33 (4):

Peter Haas, (1992) (ed) 'Knowledge, Power and International Policy Coordination, Special Issue', International Organisation, 46 (1): 1-31.

Ian R. Douglas, (1996) 'The Fatality of Globalisation', Durham, British International Studies Association, 16-18 Dec: 1-35.

Heribert Dieter, (1997) 'APEC and the WTO: Cooperation or Collision?' The Pacific Review, 10 (1): PPS

Ariff Dirlik, (1993) 'Introducing the Pacific' in Arif Dirlik (ed) What is in a Rim? Critical Perspectives on the Pacific Region Idea. Boulder: Westview Press,

Ross Garnaut, (1997) Open Regionalism in the Pacific, London: Routledge.

Walter Hatch and Kuzo Yamamura, (1996) Asia in Japan's Embrace: Building a Regional Production Alliance, Cambridge: Cambridge University Press.

Paul Hirst and Grahame Thompson, (1995) Globalisation in Question, Cambridge: Polity Press.

Richard Higgott, (1997a) 'De facto and De jure Regionalism: The Double Discourse of Region in the Asia Pacific, Global Society, 11 (2): 165-183.

------(1997b) 'Ideas and Identity in the International Political Economy of Regionalism: The Asia Pacific and Europe Compared, Kokusai Seiji, 114: 14-48.

-----(1998) 'ASEM: Towards the Institutionalisation of the East Asia-Europe Relationship? in Donald Barry and Ronald Keith (eds) Europe, North America and the Asia Pacific: Cooperation or Conflict? 
Vancouver: University of British Columbia Press, 1998

-------and Kim Richard Nossal, (1997) 'The International Politics of Liminality: Relocating Australia in the Asia Pacific?' Australian Journal of Political Science, 32 (2): 169-86.

-and Richard Stubbs, (1995) 'Competing Conceptions of Economic Regionalism: APEC versus EAEC', The Review of International Political Economy, 2(3): 549-68

W. Lee Howell, (1998) 'The Asian Contagion: Will it Get to Tokyo?' Hawaii: Pacific Forum/CSIS, 1-9.

Robert O. Keohane and Helen Milner (1996) (eds) Internationalisation and Domestic Politics, Cambridge: Cambridge University Press.

Martin Khor, (1998) 'A Poor Grade for the IMF', The Far Eastern Economic Review, January 15.

Jack Levy, (1994) 'Learning in Foreign Policy: Sweeping a Conceptual Minefield', International Organisation, 48 (2):

Andrew Mack and John Ravenhill (1994) (eds) Pacific Cooperation: Building Economic and Security Regimes in the Asia Pacific Region, Sydney: Allen and Unwin.

Richard O'Brien, (1992) Global Financial Integration: The End of Geography, London: Frances Pinter.

Kenichi Ohmae, (1990) The Borderless World, New York, Fontana.

(1995) The End of the Nation State: The Rise of Regional Economies, New York: The Free Press,

Ben Rosamond, (1996) 'European Regional Identity \& International Political Economy of European Integration' Utrecht: Conference of the International Society for the Study of European Ideas, August.

John G. Ruggie, (1982) 'International Regimes, Transactions and Changes: Embedded Liberalism in the Post War Economic Order', International Organisation, 36(4): 379-415.

------(1995) 'At home abroad: international liberalisation and domestic stability in the new world economy', Millennium, 24, 1995: PPS

Gerry Segal, (1997) 'Thinking Strategically about ASEM: The Subsidiarity Question', The Pacific Review, 10 (1): PPS

Susan Strange, (1996) The Retreat of the State, Cambridge: Cambridge University Press.

Robert Wade and Frank Veneroso (1998) The Asian Financial crisis: The Unrecognised Risk of the IMF's Asia Package', New York, Russell Sage Foundation, mimeo

Alex Wendt, (1992) 'Anarchy is What States Make of it.', International Organisation, 46 (2): 391-425

----- (1994) 'Collective Identity Formation and the International State', American Political Science Review, 88 (2): 384-97.

Michael Wensley, (1997) 'The Politics of Exclusion: Australia, Turkey and the Definition of Regionalism', The Pacific Review, 10 (4): PPS. 